\title{
Kolka Glacier and Genaldon River valley: yesterday, today, and tomorrow
}

\author{
E. V. Zaporozhchenko \\ Institute "Sevkavgiprovodhoz" \\ Pyatigorsk, Russia
}

\begin{abstract}
The biggest glacial disaster in the Russian history took place on 20 September 2002 in the mountains of North Ossetia. A huge ice-rock-water mass rushed down the Genaldon River valley with a speed of $320 \mathrm{~km} / \mathrm{h}$ from the Kolka Glacier. Having covered a distance of $18.5 \mathrm{~km}$, it was stopped by the narrows of the Skalistyy Range and filled the Karmadon hollow with 120 million $\mathrm{m}^{3}$ of deposits. The material moved beyond the hollow as a debris flow, which went down the valley (10 km) devastating all the constructions in the riverbed. A total of 125 people were reported dead or missing.

The glacier disaster of 2002 was unexpected, though such events had already occurred in 1834 and 1902 . Slow sliding up to a distance of $4.5 \mathrm{~km}$ was noticed in 1960-1970 without any disastrous consequences. In 2002, two months before the disaster, a series of collapses from the Dzhimaraj-Hokh slopes (more than $4000 \mathrm{~m}$ high) on the backside of the glacier triggered the avalanche. The last ice-mass collapse had a volume of 10 million $\mathrm{m}^{3}$. As a result, the glacier hollow formed. The material from the glacier hollow was knocked out and went down the valley with the superficial moraine. The 100-150 m high water-ice-rock mass (with air also) was moving down the 400-500 m wide valley. The area covered from the collapse zone to the narrows was $12.7 \mathrm{~km}^{2}$. The area of the ice-rock mass stopped by the "Karmadon Gates" was $2.1 \mathrm{~km}^{2}(3.6 \mathrm{~km}$ long and 135-140 m wide with an average height of $60 \mathrm{~m}$ ). The debris flow, which went down the narrows of the Skalistyy Range, covered an area of $2.5 \mathrm{~km}^{2}$, and its total volume was about 9 million $\mathrm{m}^{3}$ with a thickness of 1 to $15 \mathrm{~m}$. The flow on its way down the valley was also fed by the slope deposits and, to a greater extent, by the frontal masses of three huge ancient landslides on the left bank with a total volume of about 40 million $\mathrm{m}^{3}$. The high-energy flow undercut the toes of these landslides and displaced their material to a distance of 10-20 m.
\end{abstract}

The 2002 Genaldon catastrophe is a natural phenomenon in a long chain of geological events. Such events have been repeated for many times since the last thousand years and will also be repeated in the future.

\section{BACKGROUND}

The Caucasus Mountain Society Yearbook (1904) described the 1902 Genaldon Glacier collapse as follows: "5 July 1902. After receiving through the Chief of Pyatigorsk Kazak division a telegram from the Head of the Terskaya Region about the Genaldon Glacier collapse, the Administration of the Caucasus Mountain Society came to the decision to send one of its members on mission to the place of collapse for a detailed study and investigation of its causes. P.P. Leisinger, being an experienced mountain climber, was chosen for this mission. And, after visiting the place of collapse on 11 July and after its detailed inspection, he presented a detailed report to the Society meeting on 5 August. In order to leave a record in the Society chronicle of this interesting geological phenomenon that happened in the first year of our Society existence, we are presenting you with its description citing the eyewitnesses' evidence from Mr. Leisinger's report and the publications of that time..."
According to the Caucasus Mountain Society Yearbook (1904), "In 1902 the Genaldon Glacier collapsed two times or, to be more precise, in two steps - on the 3rd and on the 6th of July... The first glacier moved from the place known as Kolka. At first it was moving very slowly, then it rushed forward with an unprecedented speed...blocking the Genaldon Riverbed. The glacier stopped at a distance of 12 versts $(12.7 \mathrm{~km})$ from the place of its fall...the settlement of Tmenikau was destroyed... 32 people were killed...", later on 4 more people were "killed by a new glacier, which fell on 6 July..."

Besides R. R. Leisinger, the place of glacier collapse was also visited by E. A. Shteber ${ }^{1}$ and N. V. Poggenpol ${ }^{2}$ (Poggenpol 1903; Shteber 1903a, 1903b). Their observations were quite accurate in the chronological restoration of the event and professional as to its causes. All those investigators described this event as a "catastrophic" one.

Exactly 100 years later, in the 101 year of the Caucasus Mountain Society's existence, at 20:08 on the 20th of

${ }^{1}$ This article was written by a well-known Russian chemist E. A. Shteber and one month after the Kolka Glacier surge its abridged version was reprinted in the "North Ossetia" Newspaper, no. 185 (23742), 3 October 2002.

${ }^{2}$ On 17 August 1902 (Tautieva 2003). 


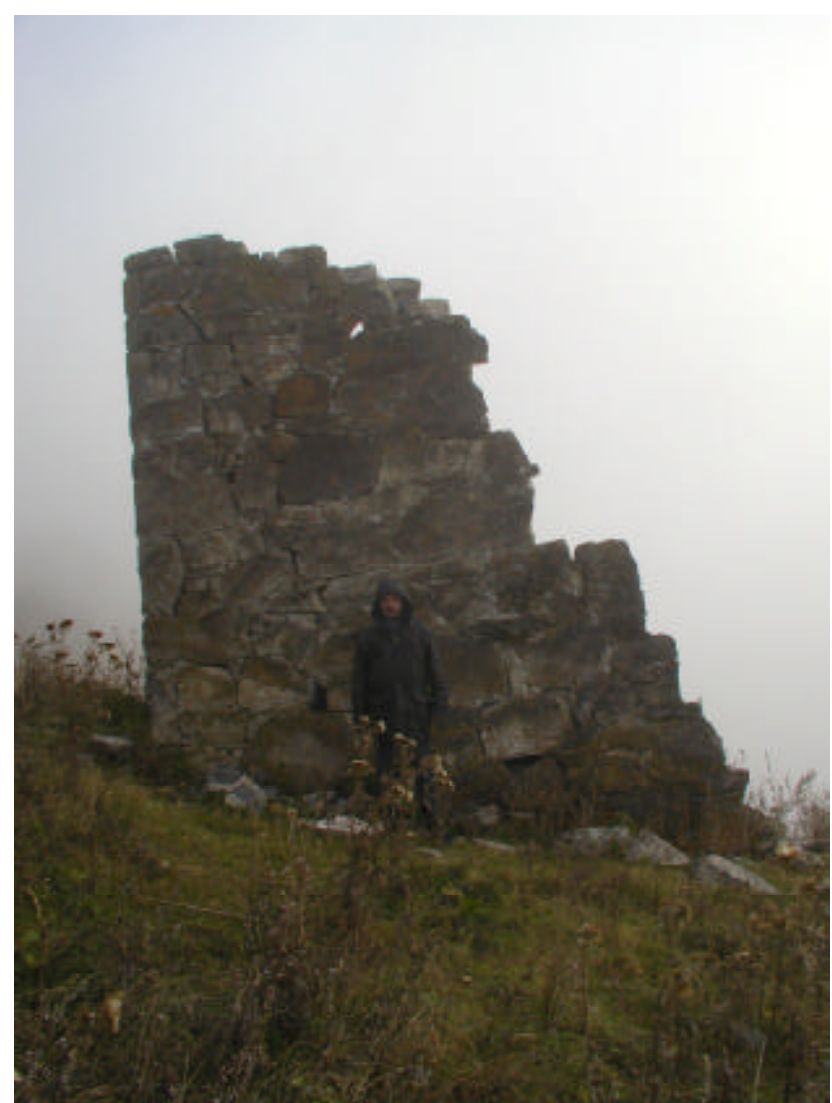

Fig. 1: The ruins of Genal village. (Photo by E. Zaporozhchenko 04.11.2002.)

September 2002 in the upper reaches of the Kolka Glacier, in the mountains of North Ossetia, there was again an ice "collapse" the result of which was another catastrophe-on a much greater scale as compared with the one of July 1902, as 19 people were killed and 106 were lost according to the reports of 19 February 2003 . This event was not only a major natural catastrophe of the year 2002 for Russia and Europe, but also a major catastrophe of glacial character for the entire world.

Here, I have presented my own views on this event based not on the numerous but contradictory, confused, and sometimes incorrect media publications, but on the materials of my research and analysis as well the study of aerial photographs obtained from S. S. Chernomorec, I. V. Galushkin, A. P. Polkvoj, and O. A. Goncharenko ${ }^{3}$.

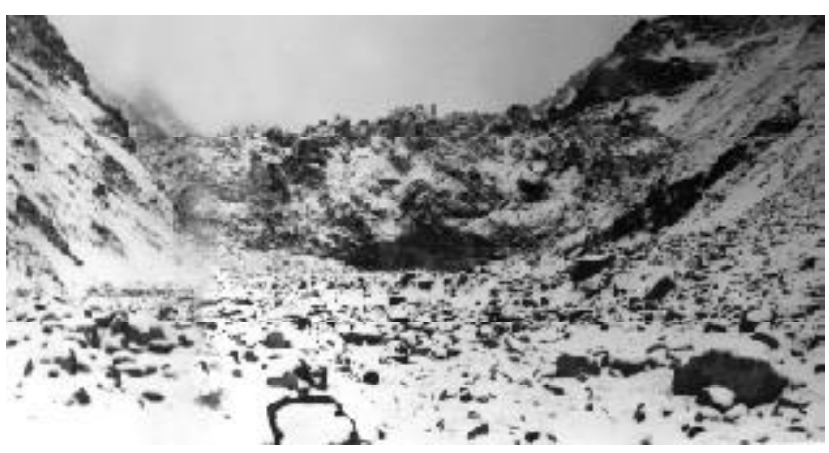

Fig. 2 : The ice front of the moving glacier Kolka is filling the valley of the Genaldon River at an altitude of $1980 \mathrm{~m}$. Verkhne-Karmadonskiey mineral springs are blocked on 29 January 1970.

\section{COLLAPSE OF GENALDON GLACIER}

In 1902, the Caucasus Mountain Society (CMS) accomplished its series of publications in the following way: "The collapses of the Genaldon Glacier, obviously, happen rather frequently and in the past may have happened even more often and on a much larger scale. This can be true because glacier boulders and stones are found in the Genaldon gorge much lower than the place reached by the flow of the 3rd and 6th of July. As R. R. Leisinger suggests, the fact that the settlements of Tmenikau and Kani had been built that high above the river should also prove it. Probably, that was a precaution taken by the ancestors who had witnessed the falls of this type" (Caucasus Mountain Society Yearbook 1904). On the attached plan entitled "the fall of the Genaldon Glacier" (Caucasus Mountain Society Yearbook 1904), there is no settlement of Genal on the right bank of the Genal River valley, opposite the N. Kani village, 130-180 $\mathrm{m}$ above the valley bottom. The ruins of this settlement can still be seen (Fig. 1). According to E. A. Shteber (1903b), that settlement was destroyed by the glacier catastrophe that took place between 1830 s and 1840s (in modern publications a different time of this event is given, as it was left only in the memory of the inhabitants-sometime between 1830 and 1890) ${ }^{4}$. In the XX century, explorers had better possibilities for establishing the dates; the earliest year - 1834 - was mentioned by Zalihanov et al. (1999) and Rototaev et al. (1983) ${ }^{5}$. N. V. Poggenpol testified in 1905 that from the watershed of the rivers Kauridon and Genaldon "one could see the settlement of Genal ..." He did not clarify

${ }^{3}$ More detailed and objective description of September 2002 event can be found in recent popular (Zaporozhchenko 2003), popularscientific (Osokin 2002), and scientific (Popovnin et al. 2003) publications.

${ }^{4}$ According to Hromovskih (1984) "In the past (before 1902, our note) a similar avalanche destroyed (?) the village of Genal and five nearby settlements".

${ }^{5}$ V. V. Agibalova gives us a later date: "Catastrophic ice-rock-flows are well known in the Genaldon River valley. The first (?) one occurred on 25 May 1885... That debris flow destroyed the village of Genal (Agibalova 1983). But the fact of its "destruction" is rather controversial. There is no evidence of such an event in the XIX century, and the mark of the highest "flushes" of September 2002 are more than $100 \mathrm{~m}$ lower than the former village buildings. The village of N. Kani situated on the Genaldon River opposite bank is about $160 \mathrm{~m}$ above the riverbed. Yet, it still exists. The only fact is that people left the village of Genal in XIX century. 
whether the settlement was inhabited or not (100 years ago the ruins of that settlement were also clearly seen). The question of the Genal settlement is important for the estimation of the nature and scale of the 1834, 1902, and 2002 catastrophes. According to the numerous post-war publications, the settlement of Genal was ruined in 1902. But that is not true! During this period of 100 years (1902-2002), one more event of "preventive character" took place - the rapid advance of the glacier (Fig. 2). It happened at the end of September $1969^{6}$ as a result of the "Kolka Glacier moving, due to the equilibrium disturbance of hanging glacier in the Maily-Dzhimaraj-Hokh range, which was also linked with the general retreat of the glacier in the Caucasus in the past 150 years" (Zaporozhchenko and Sinikov 1997). I was one of the members of the scientific study team sent by the former Soviet Government to estimate the consequences of that disaster. I also took part in an emergency flood relief project in the Genaldon and Gizeldon river valleys in 1970 and the subsequent years. These measures considered the most probable scenario of the behaviour of the ice masses, which had flowed into the Genaldon River valley from an altitude of 3000 to $2000 \mathrm{~m}$ (approximately) and blocked the source (at an altitude of $2250 \mathrm{~m}$ ) of Verkhnekarmadon mineral waters . Then, the glacier had moved for about $4 \mathrm{~km}$, having finally stopped by 10 January 1970 . The velocity of its frontal part varied from $1.5 \mathrm{~m} /$ day at the end of September 1969 to $215 \mathrm{~m} /$ day at the beginning of October 1969, and to $0.5 \mathrm{~m} /$ day at the beginning of January 1970.

\section{CONSEQUENCES OF COLLAPSE}

The project of the Sevkavgiprovodkhoz (SKGVKH) Institute was reviewed and approved by the experts in March 1970 , and the construction of basic engineering structures to protect the settlement in the Genaldon valley was accomplished by June 1970 - before the beginning of the high-water period. Soon the Geography Institute of the USSR Academy of Sciences joined the survey. In the summer of 1970, it sent an expedition to the disaster site. The expedition continued its survey till 1975, and some surveys were conducted until 1978. The results of survey were published in 1983 (Rototaev et al. 1983). They were of strictly scientific nature, but contained no estimation of the Kolka Glacier's near-future behaviour nor any recommendations for mitigative measures. But, since then, this glacier has been called a "pulsating/surging" glacier. As for the predictions on the further development process, the prognosis was published only in 1983 (cf. the predictions of SKGVH Institute appeared at the beginning of 1970). It predicted "the possible development and transformation of the glacial flows as far as the Terek River" (Rototaev et al. 1983) with the stone-mud flood-wave height up to $50 \mathrm{~m}$ in the Karmadon gorge and up to 15-20 m on the part between the Genaldon River mouth and the settlement of Gizel. The prognosis was not proved by the future events by the time when the Kolka Glacier's tongue "retreated" to its former position (before September 1969) in July 1980. But the SKGVH prognosis proved to be accurate: "catastrophic developments are unlikely, and the control measures of the project should be designed for the process of gradual ice melting with possible debris flows originating in the headwaters and floods below the Skalistyy Range. The discharge was estimated at $1 \%$ of the supply (near the settlement of Gizel), i.e. $260 \mathrm{~m}^{3} / \mathrm{sec} . . . "$ (Zaporozhchenko and Sinikov 1997). Only in June 2002, the bankfull flood discharge in the Gizel River exceeded that value. But the situation in the Kolka Glacier and in the upper reaches of the Genaldon River had nothing to do with it, since the flood had exceeded its estimated $1 \%$ of supply in the whole southern region of the North Caucasus.

It is necessary to emphasise some peculiarities of the 196970 Genaldon events in comparison with the events of 1902 :

- $\quad$ the movement of rock-ice mass - "the pulp of ice, water, and moraine" (Rototaev et al. 1983) - was fast (from $60-70 \mathrm{~km} / \mathrm{h}$ to $100 \mathrm{~km} / \mathrm{h}$ ) in 1902 , and in 1969 it was slow (a maximum of $270 \mathrm{~m} /$ day, $0.01 \mathrm{~km} / \mathrm{h})^{7}$.

- $\quad$ in July 1902, the ice mass stopped at the outlet of the present-day Tmenikau settlement, while the farthest ice front position in January 1970 was fixed at $10 \mathrm{~km}$ upstream.

In 1834 , the scale of a similar event was even greater than in 1902.

As for the triggers of the "1902 Genaldon catastrophe", it seemed that E. A. Shteber and N. V. Poggenpol were quite right defining them as "the collapse of the hanging firnglacier".

Until 2002, there had not been any serious surveys to forecast the possibility of another catastrophe in the Genaldon region - thus "the glacial catastrophe of 2002 was absolutely unexpected for both the federal and regional administrations" (Polkvoi 2002) as well as for the scientific organisations and the state departments of natural resources.

\footnotetext{
${ }^{6}$ On 6 August 1967, the debris flow triggered by heavy rains happened on the Genaldon River. "The deposits of stone, sand, and rock debris covered numerous mineral springs..., the flood wave destroyed part of the spa of the resort centre "Karmadon", a mineral spring, and a transmission line. Downstream... four houses, situated on the river terrace of 5-6 $\mathrm{m}$ high were washed away. In the narrows of the Skalistyy Range, the Genaldon River's flood waves completely devastated $6 \mathrm{~km}$ of the highway and two RCC bridges". (Agibalova 1983) (In the attached to Agibalova (1983) "Catalogue", not 2 but 4 destroyed bridges are mentioned). That debris flow was formed below the Maily and Kolka Glaciers, so those glaciers can not be related to the debris flow of 1967 !
}

${ }^{7}$ There are no witnesses of the 2002 Genaldon catastrophe, no one timed it. That was also very difficult for the researchers to fix the time and duration of the 1902 catastrophe owing to the absence of quantitative parameters. 


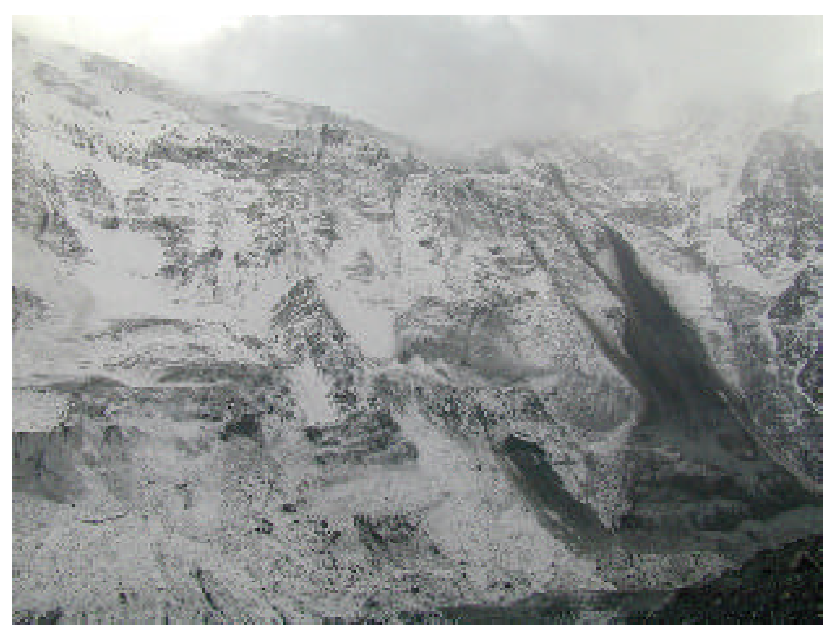

Fig. 3: The ice masses on the northern slope of the MailiDzhimaraj-Hokh mountain range. Note dark background on the right, in the outlined border of the ice avalanche of 20 Sept 2002. (Photo by O. Ryzhanov, 20 Oct 2002).

Probably, people were lulled by the published (in Zalihanov et al. 1991 and Rototaev et al. 1983) provisional prognosis of the surging glacier's 70-year cycle. Thus, according to Zalihanov et al. (1999, p. 210), "the Kolka Glacier is getting ready for another "rebellion", similar to the previous one in 60-70 years, i.e. approximately in 2040". An earlier date, which one can find in Panov et al. (2002), was 2010-2015. These figures had been probably ignored - the lessons of the past were completely forgotten at the beginning of the $21^{\text {st }}$ century.

The development of the "Karmadon" 8 resort and its facilities gave rise to the inflow of workforce into the region. The Nizhnij Karmadon village emerged close to the Genaldon riverbed (on the floodplain and lower terraces). The popular Karmadon ${ }^{9}$ mineral water well, the lower bath house with thermal mineral waters, and other spa services appeared there. At the beginning of 1970 s, a new highway leading to the resort with three tunnels in the "Karmadon Gates" section (the crossing of the Skalistyy Range) was built ${ }^{10}$. From the village of Gizel, the highway ran on the floodplain of the Gizeldon and Genaldon Rivers, and it passed just a few metres above the Genaldon River's high-water level in the narrows of the Skalistyy Range. It took now only 40-45 minutes to get to the Gornaya (Old) Saniba settlement from Vladikavkaz instead of $1.5-2$ hours by the VoennoGruzinskaya highway via the village of Chmi and the Saniban Pass. The valley bottom and the slopes of the Kauridon River (the Genaldon River's right tributary) valley were being developed very fast and new buildings began to appear on the slopes, where the wiser ancestors had never ever settled before.

Alas! As soon as the society is faced with some disaster (June 2002) or a natural catastrophe (September 2002), it seems that there is nothing more important than to fight with the destructive forces. But, as the time passes and we forget about the horrible events, we are not that eager to study and predict natural catastrophes and disasters of this kind, forgetting that nature is indifferent to us. And only we are to blame for the terrible consequences of such events, we pay the price for being so heedless of danger!

The tremor registered by the seismic stations on 20 September at 20:08 was the result of a huge ice body collapse from a great height. We can infer that this happened at the junction of the Maily-Dzhimaraj-Hokh firn-ice bridge situated on the northern slopes of Dzhimaraj-Hokh (Fig. 3), approximately at the same place shown in the picture of $\mathrm{N}$. B. Poggenpol (from his own photo) - "the northern slope of Mt. Dzhimaraj-Hokh after the collapse of 1903" (Panov et al. 2002). A drawing made by N. B. Poggenpol ${ }^{11}$ shows a larger section (towards Maily) than the one of 2002.

Goncharenko (2002) and Polkvoy (2002) defined the upper margin of scar at an altitude of $4000 \mathrm{~m}$ and the relative relief of the steep route of ice movement about 1,000 m (cf., according to Ottwater (1980), it was $940 \mathrm{~m})$. In the newspapers, the volume of ice collapse was estimated at 510 million $\mathrm{m}^{3}$.

Further development of the catastrophe (after the collapse) is based mainly on the description of Popovnin et al. (2003). According to them, a major part of the Kolka Glacier was, probably, "surged out" by the collapse and pushed down the valley. Then, this gigantic mass rushed down, involving into its movement various deposits, water, and dead ice. Part of the mass rushed down the cut, through the Kolka runoff. Another part rolled over the moraine (which divides the Kolka Glacier and the Maily Glacier), went down the Maily Glacier apron, and joined with the rest of the mass. After hitting the Skalistyy Range (the southern scarp of the "Karmadon Gates"), the major ice mass stopped and filled up the Karmadon depression. Part of the ice masses reached the Kauridon River mouth, where a large dammed lake was formed later. At the final stage of the catastrophe, the ice masses stopped at the Skalistyy Range and a mudflow was formed. The $30 \mathrm{~m}$ high mudflow wave rushed down the valley. After being ejected through a narrow canyon, its amplitude lowered to about 3-4 $\mathrm{m}$ in the vicinity of the confluence of the Genaldon and Gizeldon Rivers. In the Gizeldon River, debris-flow deposits were accumulated. From the upstream

\footnotetext{
${ }^{8}$ Opened in 1962

${ }^{9}$ Nizhne-Karmadon mineral spring

${ }^{10}$ As a reaction to the August 1967 debris flows events

${ }^{11}$ N. V. Poggenpol, the first mountaineer who conquered Mt. Maily (4601 m) in 1902 from the ice- and snow-covered south face of Gergety Glac
} 


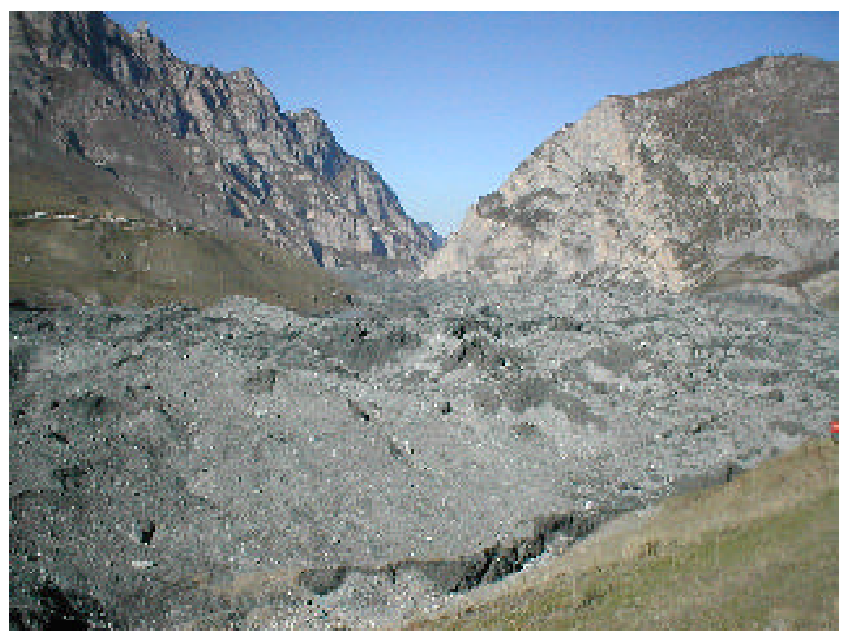

Fig. 4: The rock-ice blocking masses near the "Karmadon Gates" (Photo by E. Zaporozhchenko, 6 Oct 2002)

of the village of Gizel, the debris flow became a sedimentladen flood. It would be more correct to speak not about "ice masses" but "rock-ice masses", which include about $30 \%$ of rock material with clasts of a very wide range of sizes and about $70 \%$ of ice itself. This mass moved down a distance of about $19 \mathrm{~km}$ from the place of its collapse on the Kolka Glacier down to the narrows of the Skalistyy Range (Fig. 4).

After flowing into the Gizeldon River, the mudflow masses dammed it. Based on the high water marks (HWM) estimated by the SKGVH in the Genaldon River mouth, the debris flow of September 2002 had an incline towards the left bank: the difference between the right and the left bank levels was 4.3- $6.0 \mathrm{~m}$ (Sevkavgiprovodhkoz 2003). The 2-3 m high backwater flow was expected in 2003 due to the obstruction of flow in the narrow Gizeldon River valley, but there is no danger to the lower part of the valley (the washout of the dam on the Gizeldon River happened on the very first days of its existence).

Using the satellite imageries, the total "disaster zone" was estimated at $12.7 \mathrm{~km}^{2}$. The length of deposited rock-ice mass was estimated at $3.6 \mathrm{~km}$ with an area of about $2.1 \mathrm{~km}^{2}$. Its average thickness was about $60 \mathrm{~m}$ and the total ice mass volume was about 115 million $\mathrm{m}^{3}\left( \pm 10\right.$ million $\left.\mathrm{m}^{3}\right)$. Since no geological or topographic surveys were conducted, nor a comparison of aerial photos before and after the catastrophe was made, we should rely on the given figures. Also, according to Popovnin et al. (2003), "After the Karmadon Gates the stone-mudflow moved for $17 \mathrm{~km}$ with $3.0 \mathrm{~km}^{2}$ of disaster zone. The volume of mudflow deposits was ...3 -5 million $\mathrm{m}^{3} . "$

The average speed of the water-rock-ice mass movement, from the place of the hanging glacier collapse (with the inclusion of the broken rock material from the fault bench) down to the Skalistyy Range where the mass stopped, can be estimated according to the following data:
- 5 minutesand 30 seconds passed from the moment, when the seismic tremor caused by the hanging ice masses collapse on the Kolka Glacier, was registered to the moment when the high-voltage electric power line from Karmadon to Gornaya Saniba was turned off ;

- 3 minutes and 30 seconds passed from the first to the second registered oscillation, most likelycaused by the fronts of the moving masses that hit the rocks of the "Karmadon Gates".

It means that in the first case, the ice masses travelled for $16-16.5 \mathrm{~km}$ (based on the 1:50,000 scale maps) with an average speed of about $180 \mathrm{~km} / \mathrm{h}$ (Panov et al. 2002, estimated the speed at $200 \mathrm{~km} / \mathrm{h}$ ). In the second case, for the $18.5 \mathrm{~km}$, the average speed was $320 \mathrm{~km} /$ hour. As the high voltage electric power line that crosses the valleys was locatedat an elevation less than $100 \mathrm{~m}$ higher than the riverbed level in the passage range, it is possible that its cut off occurred after the frontal mass had passed under the power line.

The speed of $320 \mathrm{~km} / \mathrm{h}$ could not be reached without the air participation. Even in the case of an ideal slip along the bottom water layer, the average speed in the section of 12.5 $\mathrm{km}$ (between the point of confluence of the Kolka and the Mainly Rivers, and the "Karmadon Gates") could not exceed $140 \mathrm{~km} / \mathrm{h}$ according to the calculations (Popovnin et al. 2003). Apparently, here we have the situation that often accompanies the ice and rock collapses from relatively high altitudes (Hromovskih 1984). At the moment of the collapse mass landing, and possibly even during the fall, the entrapped air is greatly compressed and "is used" as the unique lubricant for the subsequent movement. Even if, for some reasons (e.g., permeability), the air cushion disappeared from under the base of the flow in the process of motion, the air breaking through the layer of fragments considerably decreased the friction between the moving masses of different particles, which naturally contributed to an increase in the mass mobility. In this case, a speed ${ }^{3}$ of $180 \mathrm{~km} / \mathrm{h}$ is quite possible and this speed characterises the air-waterrock-ice masses movement. And a speed of $300 \mathrm{~km} / \mathrm{h}$ is not the higher limit if the mass moves on the air cushion. Thus, the Huascaran "avalanche" in the Andes of Peru, consisting of a mixture of snow, ice, water, and rock fragments, was supposedly moving on an air cushion and its speed "reached a value of $280-335 \mathrm{~km} / \mathrm{h}$ and in some particular sections, it was even $450 \mathrm{~km} / \mathrm{h} . ”(H r o m o v s k i h ~ 1984)$.

It is necessary to emphasise that, taking into consideration the Genaldon tract, it is possible to estimate only an average speed for such a sufficiently extensive segment (16-19 km). Using the data of Vinogradov (1977), let us draw a comparison between the gradients of the movement tract of the Huascaran "avalanche" (1970) and the Kolka "avalanche" (2002). The gradients of the Genaldon River valley and the absolute marks were taken from the field survey of the area on a scale of 1:50,000 in 1984. 


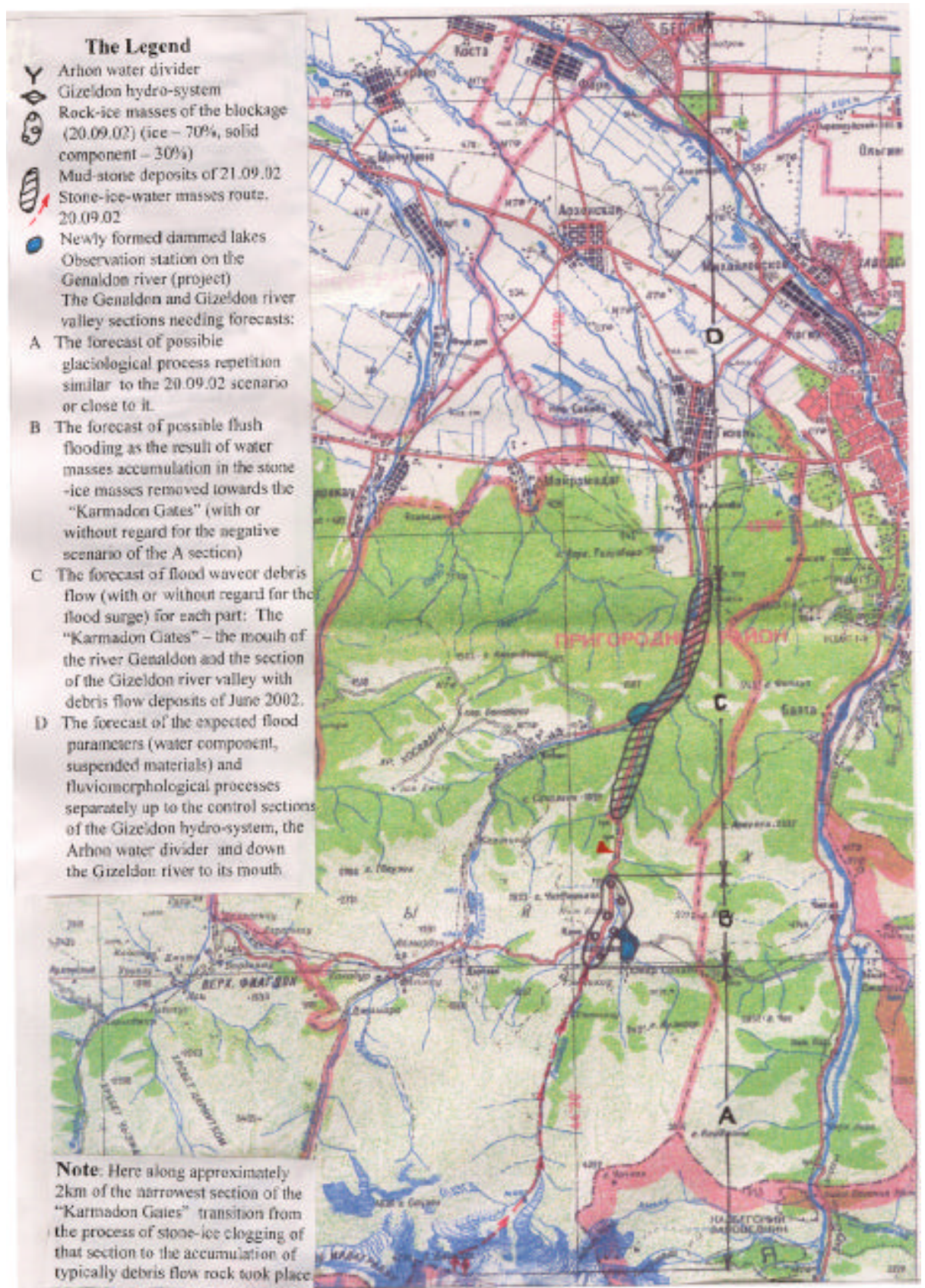

Fig. 5: Map of Genaldon glacier catastrophe of 2002

The average gradient of the $14 \mathrm{~km}$ long section from the foot of Nevada-Huascaran to Ungai was $13^{\circ}$, the gradient of the $18.5 \mathrm{~km}$ long section from the Kolka Glacier rear part to the "Karmadon Gates" was $7^{\circ}$. It is evident that the gradient of the Genaldon riverbed was considerably less than that of the Huascaran event. In August 1974, the torn-off ice masses from the apron of the surging Didal Glacier in the Pamir rushed with a tremendous speed of $70 \mathrm{~km} / \mathrm{h}$ for about $3 \mathrm{~km}$ on the gorge bottom with a gradient of only $20^{\circ}$ (Yablokov 1975).

The consequences of the Kolka Glacier collapse and the undertaken rescue and rehabilitation measures up to February 2003 are depicted in Fig. 5.
After 20 September 2002 (the emergency stage) the following activities were undertaken:

- $\quad$ people search and rescue; and

- Dam break assessment of Lake "Gornaya Saniba”.

The lake came into existence due to the blockage of the Fardon and Kauridon Rivers and was rapidly being filled up. It was inundating and damaging buildings and other infrastructures (Fig. 6). 


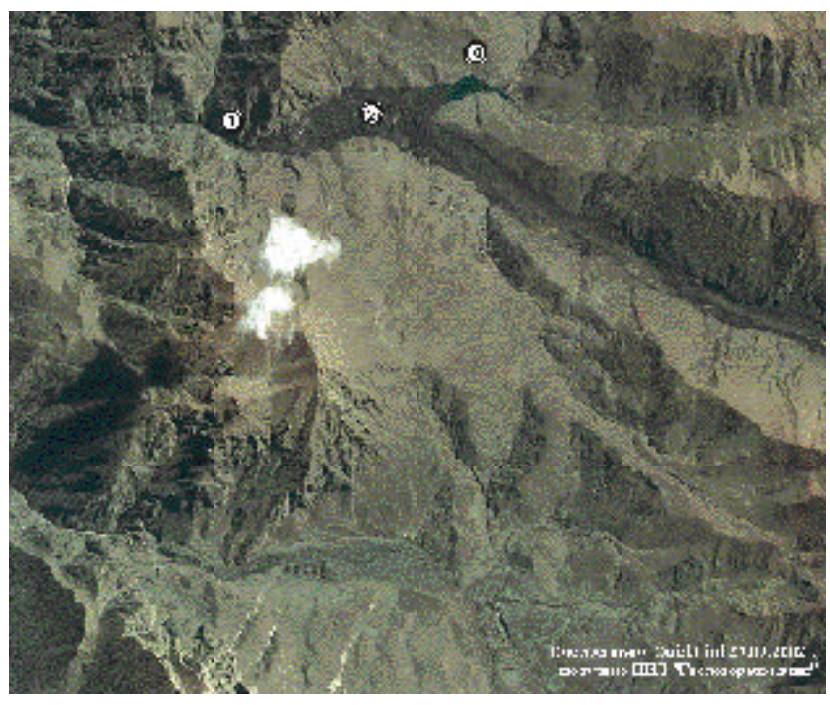

Fig. 6.: Satellite imagery of the Genaldon river valley: 1 "The Karmadon Gates"; 2 - rock-ice masses of 20 Sept 2002 blockage; 3 - newly formed Lake "Gornaya Saniba"

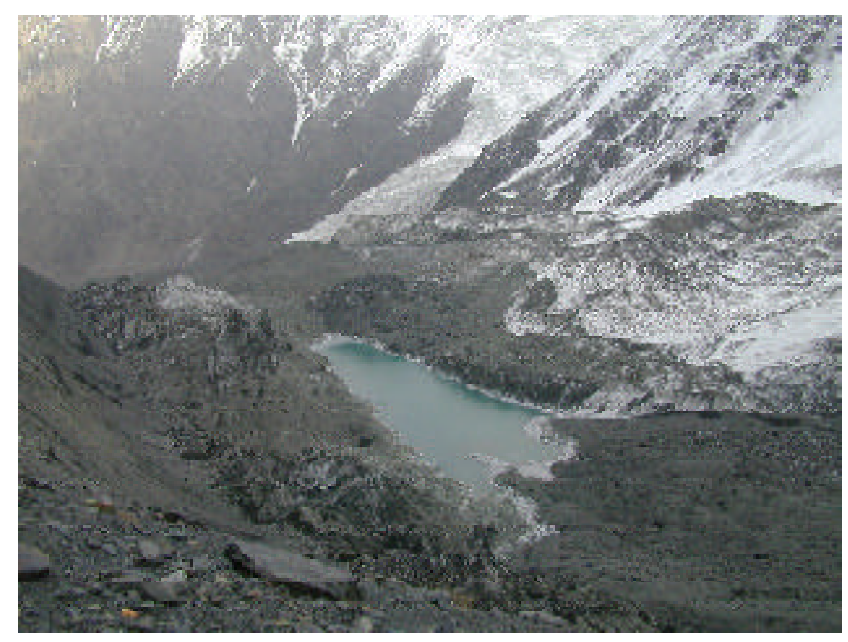

Fig. 8: 20.10.2002. New lake formation in the mountain valley previously covered by the Kolka Glacier (till 20 Sept 2002). (Photo by O. Ryzhanov)

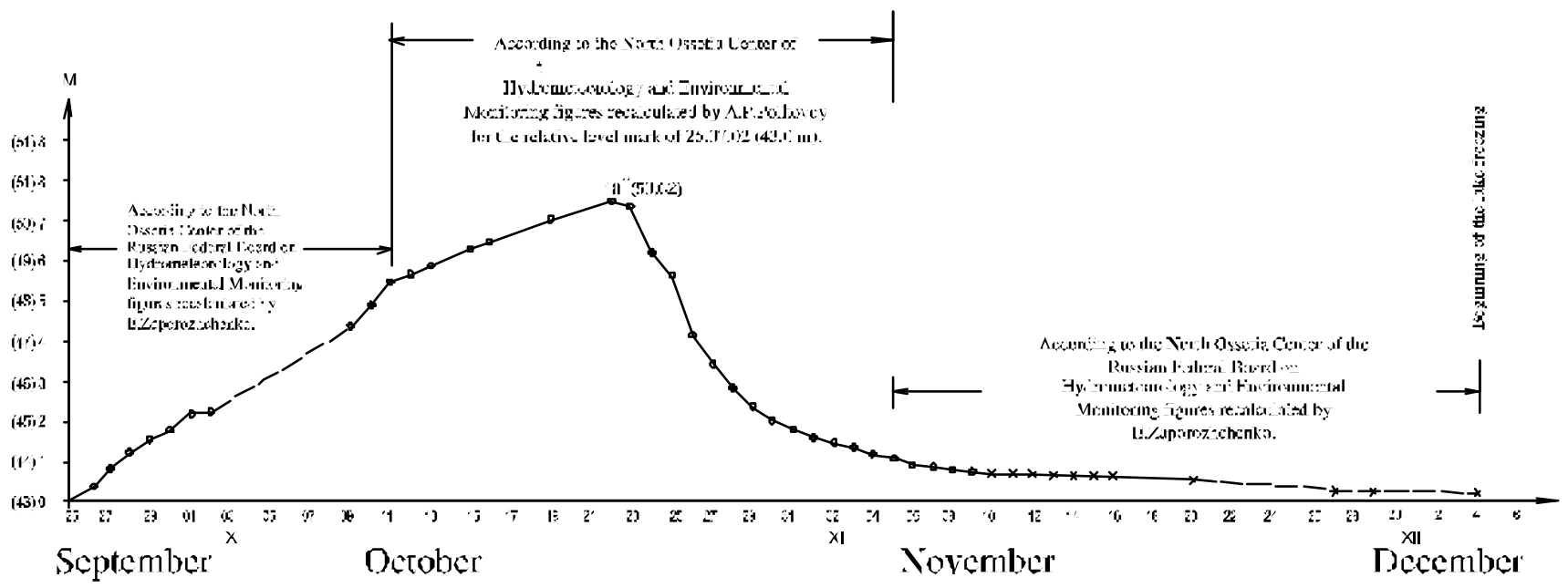

Fig. 7: The diagram of Lake “Gornaya Saniba” water level fluctuations

The Ministry of Emergency Situations of Russia and its regional organisations were in charge of the first task, whereas the SKGVKH (after 2 October 2002) was in charge of the second activity. By 3 October 2002, about 2, 5 million $\mathrm{m}^{3}$ of water had accumulated in the artificial lake (pers. comm. with V. N. Drobyshev, "Sevosgeoeko"), and the water level kept rising rapidly. On 3 October 2002, it was forecasted that from 18 October 2002 the overflow would begin, which would end up with flooding the dam weir on 23 October 2002. After this, until the spring of 2003 there would be no water level rise and the water level would begin to drop. In this case, the possibility of surge wave formation was excluded. The whole process went in accordance with the SKGVKH forecast up to the first ten-day period of December 2002, when the lake finally froze (Fig. 7). The water level returned to the mark, fixed on 25 September 2002, and the natural water discharge was 0.5 million $\mathrm{m}^{3}$. The water level monitoring was terminated on 9 January 2003.

Owing to the lack of any previous monitoring data, the SKGVKH forecast was based only on the "Experts' judgement". Therefore, it was felt necessary to take some precautionary measures in case of some unforeseen situations. It was planned to dig out a drainage channel on the right bank and reduce the lake water level to that of 20 October 2002. The problem became less hazardous after 23 
October 2002, but the further hydrodynamic behaviour of the dam remained obscure. The dam was becoming substantially compacted owing to the loss of its ice core due to meting. The forecast for the forthcoming spring and summer is still to be made ${ }^{12}$. However, there are hundreds of cases when rivers were dammed with ice or debris. In most of the cases, if human settlements were situated downstream, partial or complete artificial draining of such lakes was carried out - either immediately after the lake was formed or after a certain period of time depending on the situation (Hromovskih 1984).

Until now (March 2003), there is no monitoring system for the September 2002 catastrophe, nor any new surveys and quantitative measurements needed for further engineering calculations are being gathered. From the beginning of the warm period of 2003 and the following years, the problem of protective measures for the land in the valley and the population there will become acute, especially under the new (changed after 20 September 2002) hydrological landscape conditions (against the background of the destroyed hydraulic and bank-protecting structures and the deposits accumulated after the flood of June 2002).

We also have to answer another question: Is a new ice masses fall from the slopes of Dzhimaraj-Hokh and from the western part of the Maili-Dzhimaraj-Hokh firn-ice col possible? If the ice-rock avalanche hits the rear part of the Kolka Glacier, how it will affect the transportation process in the "Kolka Glacier - Tmenikau village strip"? In other words, will the new rock-ice-water masses reach the rear part of the existing blockage? After 20 September 2002, the situation on this transit tract has changed radically. The moving masses "have cleaned out" the Genaldon River valley bottom and its slopes up toan average height of 100-150 m, and in the glacier trough bed a lake has been formed (Fig. 8). The role of lake in the flow formation process and its characteristics will have to be determined. According to the opinion of those who became acquainted with the glaciological situation at the absolute height of 3,300 - 4,300 $\mathrm{m}$ in September - October 2003 (the mountaineer V. N. Ryzhanov, for instance), it is believed that the ice mass with the volume of $>10$ million $\mathrm{m}^{3}$ is ready to drop to the Kolka Glacier.

\section{SIMILAR CATASTROPHES IN THE WORLD}

In connection with this, let us again focus our attention on similar catastrophes in the Cordillera-Blanca (Peru) in 1962 and 1970. The first catastrophe "was not caused by an earthquake, but proved to be the first of the whole sequence of the well known ice-rock avalanches formed in that region" (Hromovskih 1984). It broke out on 10 January 1962. A gigantic block broke off from the ice cap of Nevada-
Huascaran ("a mountain peak covered with eternal snows"). After falling about $1000 \mathrm{~m}$ vertically (according to other data, $600 \mathrm{~m}$ ), this huge mass of snow and ice with a volume of 23 million $\mathrm{m}^{3}$ collapsed on the glacier situated below. Due to the collision, the ice was pulverised. According to Ottwater (1980), "in the cirque below Huascaran peak, a terrible monster was born: the mixture of crushed ice, broken blocks of sand and stones from the moraine, and melted water. And this snake with the head of more than 50 metres rushed down the gorge, wriggling and coiling". Taking with it new masses of loose material, the avalanche on its route greatly increased in volume: up to 5-10 million $\mathrm{m}^{3}$. Having covered a distance of $16 \mathrm{~km}$ (!) the avalanche dammed the Santa River. About 4000 people were killed as a result of this rock-ice surge and a dam washout. The mechanism of the Huascaran avalanche formation (1962) is considered “...to be fairy simple. The snow and ice masses accumulating on the slopes of Huascaran moved down slowly, forming a gigantic hanging cap on the edge of steep cliffs. When the weight of this cap reached a critical mass, part of it broke off and an avalanche originated. For many decades, these avalanches did not do any harm to the population of the region. But in 1962, the situation changed. The super-abundant snowfalls in the winter of 1961 in the Cordillera-Blanca greatly increased the quantity and thickness of ice in the mountain peak glaciers. The subsequent extraordinarily humid and rainy summer aggravated the situation... This led to a rapid increase of tension in its thickness (in the snow-ice cap), and finally to the tearing-off of a heavy layer of snow and ice. The frontal part broke off and fell..." (Hromovskih 1984).

According to the Hydrometeorological Centre of Russia, the amount of 2001-2002 winter snowfall in the Caucasus exceeded the normal rate by about $30 \%$, and the rains of June 2002 led to a catastrophic flood in the Terek River basin (also in the Kuban and Kuma Rivers basins).

On 31 May 1970, a powerful earthquake again caused the Huascaran "avalanche". "Its destruction rate, height of fall, speed, and probably its volume are considered to be unprecedented" (Hromovskih 1984). Again "a huge block of rock-ice material with the volume of several million cubic metres broke off from Mt. Huascaran ${ }^{13}$. From almost one kilometre height, this mass plunged into the glacier and, after passing $2.4 \mathrm{~km}$ along it, rushed downward, gaining speed...During several minutes from the beginning of the earthquake the avalanche passed $16 \mathrm{~km}$ from Huascaran Peak down to the Santa River, blocked this river, and forced it to flow in the opposite direction for a while. The total mass of the moving crushed rock, large pieces of ice, and loose glacial and other deposits taken with the flow on its way comprised about 50 million $\mathrm{m}^{3}$ "A tremendous ${ }^{14}$ rock-mud flow"

\footnotetext{
${ }^{12}$ According to the SKGVH estimations (Sevkavgiprovodhkoz 2003) the maximum surplus inflow of the melting ice masses, accumulated in the Karmadon basin after September 2002, is about $5 \mathrm{~m}^{3} / \mathrm{s}$ (with a maximum day temperature of $37^{\circ} \mathrm{C}$ ).

${ }^{13}$ In the report of Vinogradov (1977), a different volume (from 8 to 15 million $\mathrm{m}^{3}$ ) of the dislodged masses is given, though the latter figure includes, according to $\mathrm{U}$. Vinogradov, approximately 5 million $\mathrm{m}^{3}$ of firn from the lower glacier.

${ }^{14}$ According to Panov et al. (2002), from 23 to 42 million $\mathrm{m}^{3}$
} 


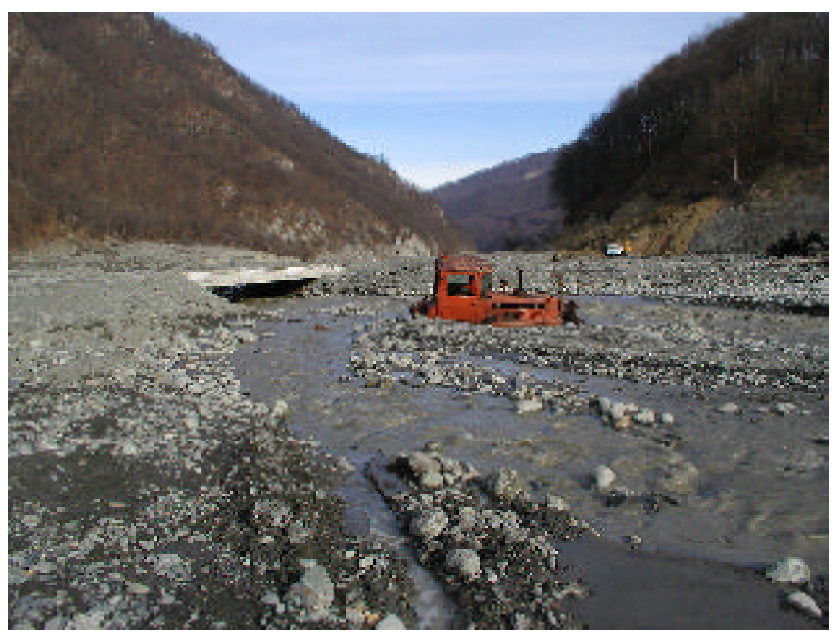

Fig. 9: Debris flow stone-mud masses in the mouth of the Genaldon river. The downstream view. (Photo by E. Zaporozhchrnko, 6 Dec 2002).

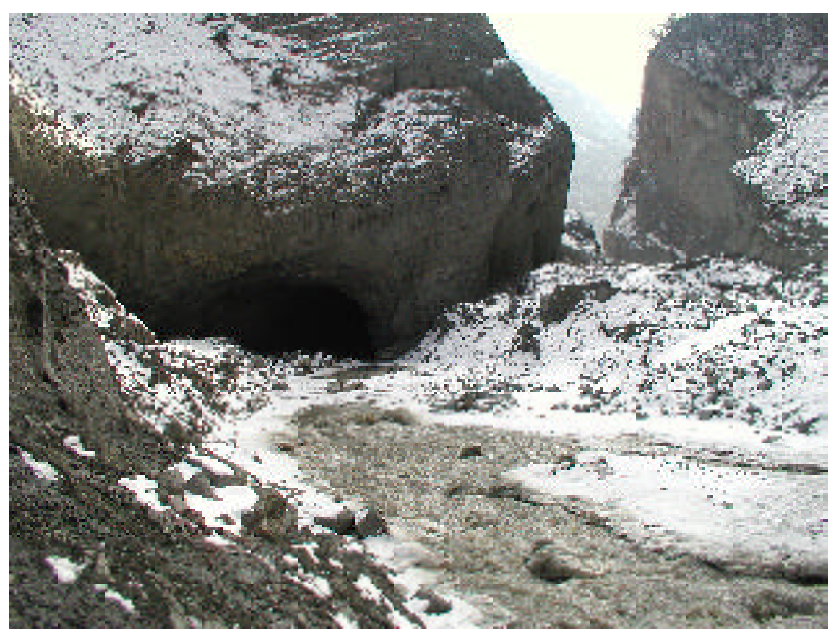

Fig. 11: The Genaldon River is flowing through the south end of highway tunnel remnant.

(Photo by E. Zaporozhchenko, 20 Feb 2003).

appeared in the frontal part of the Huascaran avalanche.... The speed of that flow reached $36 \mathrm{~km} / \mathrm{h}$..." (Hromovskih 1984).

The destructive activity of the Huascaran avalanche and its mud or debris flow led to much more tragic results than the Genaldon catastrophe: “... in the Llanganuko valley Ranrairka settlement (rebuilt after the catastrophe of 1962 in a place situated further south) was again almost completely destroyed ". We shouldn't forget that the "avalanche" of 1970 "repeated" itself (after 8 years). But, in other respects, we can trace a lot of analogies in the Peruvian events of 1962 and 1970, and the Karmadon catastrophe of 2002.

But then, the need for an urgent project development becomes absolutely obvious. Based on a reliable prognosis

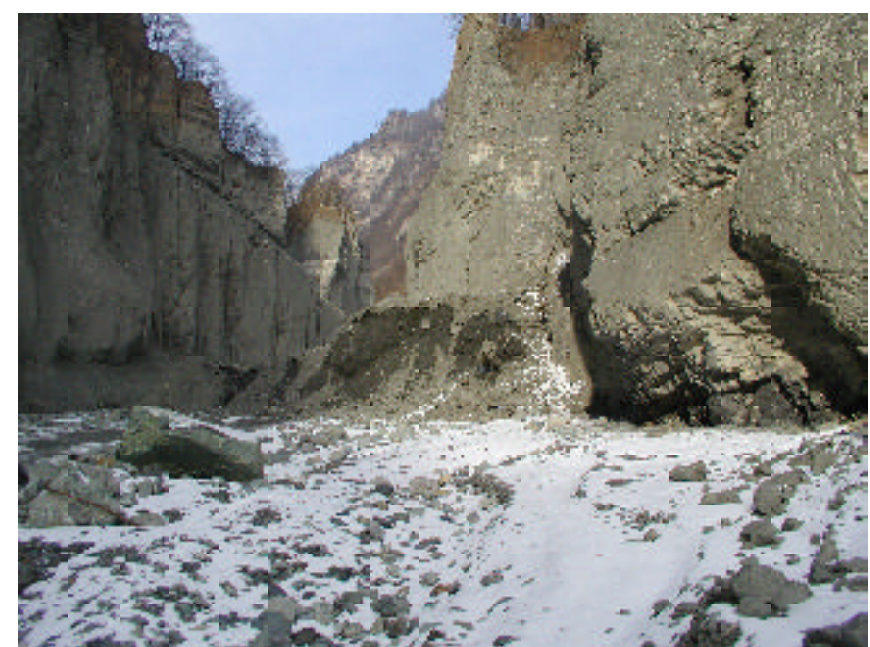

Fig. 10: An ice block on the Genaldon river's right bank (the lower highway tunnel section). The downstream view. (Photo by E. Zaporozhchenko 20 Feb 2003).

(a series of forecasts on a number of scenarios with acceptable selection of technical, economic, and social indices), that project would determine measures for prevention and protection of the territories and the population from the consequences of the glacier surge of 20 September 2002 for the nearest (till the high-water period of 2003) and more distant future. According to the normative documents, these measures must be put into practice in the spring of 2003. But, the state organs in charge of security are still waiting. No forecast study was initiated nor any engineering decisions were made even by the end of February 2003.

\section{DISCUSSION AND CONCLUSIONS}

The term "glacier collapse" has gained a firm foothold in the mass media since the beginning of 2002. Its meaning includes the ice mass fall from a high altitude, the Kolka Glacier movement (for about $5 \mathrm{~km}$ ), the water-rock-ice mass transition on the route (for about $11 \mathrm{~km}$ ), the rock-ice mass accumulation (for about $5 \mathrm{~km}$, up to the outlet of "Karmadon Gates"), and also the rock-mud debris flow deposition in the Genaldon and Gizeldon Rivers below the "Karmadon Gates" (for about $12 \mathrm{~km}$, Fig. 9). A majority of researches support the version that initially a great amount of ice and rock material (up to 5-10 million $\mathrm{m}^{3}$ ) fell on the Kolka Glacier. We are aware of only one different opinion of L. Denisova (Moscow) - “...there was no collapse...the glacier could not but move... according to the principle of glacier pulsating/surging... everything was similar to the 1969 events, when the Kolka Glacier surged..." (Tautieva 2003).

The exit from the "Karmadon Gates" is situated on the lower section (downstream of the Karmadon River) of the highway tunnel (destroyed) on the right bank. Large ice blocks were still seen near the north portal of the tunnel at the end of February 2003 (Fig. 10), near the south portal (Fig. 11), the 
river flows out from under the rock-ice blockage (the bottom is raised about 7-8 $\mathrm{m}$ above the level of September 2002). During the first days after the debris flow, the ice blocks could be found $10 \mathrm{~km}$ downstream than the "Karmadon Gates"!

There are still no substantial arguments for serious scientific generalisations, which would help us understand the reasons of the 2002 Genaldon glacial catastrophe ${ }^{15}$ - an event of definitely global significance. Its only "rivals" are the above mentioned Huaskaran "avalanches" of 1962 and 1970.

"We couldn't disagree with M. Ottwater that the Huascaran avalanche of 1962 could have been predicted and its tragic consequences could have been avoided if the permanent field observations of the snow-ice caps had been organised. Yet those observations had not been organised even after the disaster... The Huascaran valley dwellers had to live through another catastrophe, much more tragic than the previous avalanche of 1962" (Hromovskih 1984).

The 2002 Genaldon catastrophe is a natural phenomenon in a long chain of geological events, the events that have been repeated for many times since the last thousand years and will surely be repeated in the future. That is an unfavourable but quite natural conclusion corroborated by the experience of the study of similar events. A powerful earthquake in the Kazbek region is not likely to happen very soon, but just a slight seismic wave would be enough for still another collapse of several million $\mathrm{m}^{3}$ of firn, ice, and rock mass from the Maily-Dzhimaraj-Hokh col on the Kolka Glacier cirque.

\footnotetext{
${ }^{15}$ According to Panov et al. (2002), "The reason for the hanging glacier collapse was an earthquake (4-5 on the Richter scale), registered on 8 September 2002 on the Caucasus Black Sea coast. Its echoes of $1.0-1.5$ (?) reached the Kolka Glacier and resulted in the micro crack formation in the hanging glacier and, probably, in the bedrock, increased its sliding speed, and led to the glacier fall". There is no factual proof of this phenomenon, and the earthquakes of such type happen in the Caucasus Mountains tens or even hundreds of times every year (e.g., see Panov et al. 2002). Also according to them, "The glacier stability could have been influenced by the weather conditions of recent years - abundance of atmospheric precipitation not only in cold but also in warm periods..."
}

\section{REFERENCES}

Agibalova, V. V. 1983, Debris-flows of North Ossetia. Ordzhonikidze "Ir" (in Russian).

Goncharenko, O. A., 2002, How will the ice "monster" behave? North Ossetia, no. 179 (23736) 25.02 (in Russian).

Hromovskih, V. S., 1984, The rock dragon. Moscow: Mysl, (in Russian).

Osokin, N. I., 2002, Glacier catastrophe in Ossetia. Geography, no. 43 (674), 16-22 (in Russian).

Ottwater, M., 1980, Avalanches Hunters. Moscow: "Mir" (in Russian).

Panov, V. D., Ilichev, U. T., and Lurier, P. M. 2002, The glacier collapse in the mountains of North Ossetia. Meteorology and hydrology, v. 12 (in Russian).

Poggenpol, N. V., 1903, Across the north valleys of the Kazbek massif and the first ascent of Maily-Kokh. Russian Mountain Society Yearbook, v. 3, Moscow (in Russian).

Polkvoi, A. P., 2002, What are the reasons for ice avalanches? North Ossetia, no. 178 (23735) 24.09 (in Russian).

Popovnin, V. V., Petrakov, D. A., and Tutubalina, O. V., 2003, Chernomorets S. S. Glacier catastrophe of 2002 in North Ossetia. Kriosphera Zemli. v. 7, 1 (in Russian).

Rototaev, K. P., Hodakov, V. G., and Krenke, A. N., 1983, Study of the surging Kolka Glacier Moscow: "Nauka" (in Russian).

Sevkavgiprovodhkoz, 2003, Work Project. Hydrological research for the bridge across the Genaldon River on the $11.1 \mathrm{~km}$ of the Gizel - Karmadon - Dargavs - Dzuarikau highway. Technical account. OAO "Sevkavgiprovodhkoz", no. 36-185/502, Pyatigorsk (in Russian).

Shteber, E. A., 1903a, The trip to the Genaldon in 1902. The Saniban catastrophe. The Caucasus Mountain club notes (in Russian).

Shteber, E. A., 1903b, Glacier collapses in the Genaldon River upper reaches in the Caucasus. Vladikavkaz: Terski bulletin. Ekaterinoslav Scientific Society, v. 2, no. 7 (in Russian).

Tautieva, T., 2003, The Kolka Glacier will remind of itself again. North Ossetia. no. 31 (23832) 15.02.2003 (in Russian).

The Caucasus Mountain Society Yearbook, 1904, The Genaldon Glacier collapse, no. 1, 1902, 1903. Pyatigorsk (in Russian).

Vinogradov, U. B., 1977, Glacier surge floods and debris-flows. Leningrad Gidrometeoizdat (in Russian).

Yablokov, A. A., 1975, Ice flood. Meteorology and Hydrology, no. 7 (in Russian).

Zalihanov, M. C., Efremov, U. V., and Popov, V. D., 1999, The Caucasus ice crown. Nalchick: publishing center "Elf-Fa" (in Russian).

Zaporozhchenko, E. V., 2003, The Kolka Glacier surge of September 20, 2002 and its consequences. Vestnik KGO, no. 4, Pyatigorsk (in Russian).

Zaporozhchenko, E. V., and Sinikov, V. A., 1997, Preventive measures in the Gizeldon River valley caused by the Kolka Glacier surge. "Engineering defence against dangerous geological processes", no. 7, Pyatigorsk (in Russian). 